\title{
SANKSI ADAT DELIK PERZINAHAN (UMOAPI) DALAM PERSPEKTIF HUKUM PIDANA ADAT TOLAKI
}

\author{
Handrawan \\ Fakultas Hukum Universitas Haluoleo Kendari \\ e-mail: handrawansaranani84@gmail.com
}

\begin{abstract}
ABSTRAK
Persetubuhan atau perzinahan baik menurut hukum pidana dan hukum adat Tolaki memiliki pandangan yang sama di mana persetubuhan atau perzinahan merupakan perbuatan melawan hukum dan patut untuk diberikan sanksi pidana atas perbuatan pidana tersebut. Namun demikian, hukum adat Tolaki dalam konsep klasifikasi persetubuhan lebih mengatur secara komprehensif tentang perzinahan, di mana perbuatan zina tidak hanya terbatas pada mereka yang telah terikat dengan perkawinan sebagaimana dimaksud dalam Pasal $27 \mathrm{BW}$ tetapi mengikat pula bagi mereka yang belum terikat perkawinan dengan penerapan sanksi adat Tolaki yang berbeda-beda berdasarkan klasifikasi jenis perzinahannya atau umoapi.
\end{abstract}

Kata Kunci: sanksi, adat, perzinahan.

\begin{abstract}
Promiscuity or adultery either according to the criminal law and the Tolaki customary law, have the same view where promiscuity or adultery is against the law and so it is worth to be given criminal sanctions upon the criminal act. Nevertheless, Tolaki customary law regulated about promiscuity comprehensively about adultery, where the Act of adultery is not just limited to those who had been marriage as stipulated in article $27 \mathrm{BW}$ but also bind those who are not marriage yet, with the application of Tolaki different customs sanctions based on classification type of the fornication or umoapi.
\end{abstract}

Keywords: sanction, custom, adultery.

\section{PENDAHULUAN}

Lahirnya kodifikasi Peraturan Hukum Pidana atau KUHP Tahun 1918 menjadi jawaban penting bagi bangsa Indonesia sebagai dasar terhadap penghapusan konsep dualisme hukum pidana yang dapat mempersulit nilai-nilai kebudayaan bangsa Indonesia. Pada tahun 1946 Wetboek Van Strafrecht Voor Nederlandsch-Indie mengalami perubahan menjadi Wetboek Van Strafrecht Voor Indonesie yang dinyatakan berlaku di Indonesia sebagai salah satu Kitab Undang-Undang Hukum Pidana (yang selanjutnya disebut KUHP) yang berlaku secara universal di wilayah Republik Indonesia.

Pentingnya hukum pidana sebagai pedoman dalam mengatur hidup kemasyarakatan maupun menyelenggarakan tata aturan dalam masyarakat menjadi suatu hal yang sangat urgen, sehingga fungsi hukum pidana secara khusus dalam hal melindungi kepentingan hukum (nyawa, badan, kehormatan, harta, dan kemerdekaan) dari perbuatan yang hendak merusaknya dengan memberikan sanksi berupa pidana menjadi tujuan utama lahirnya hukum pidana.

Konsep ideal yang ditawarkan dengan lahirnya produk hukum (undang-undang) dan segala aspek yang melandasi lahirnya undang-undang tersebut, ternyata juga memberikan berbagai permasalahan hukum yang disebabkan kekurangpahaman konsep hukum tersebut terhadap prinsip-prinsip yang hidup pada tatanan budaya bangsa Indonesia. Dominasi mazhab Positivisme dalam hukum pidana Indonesia sebagai akibat dimarginalkannya hukum pidana tidak tertulis atau living law menjadi salah satu hal yang menyebabkan nilai-nilai kebudayaan dari bangsa Indonesia terabaikan khususnya terhadap pengakuan hukum pidana adat di Indonesia.

Jika ditinjau dari perspektif mazhab hukum, keberadaan hukum tidak tertulis masih dapat diakui sebagai suatu ketentuan hukum yang berlaku bagi masyarakat dan hal tersebut dibuktikan dengan 
corak berpikir mazhab Utilitarianism oleh Jeremy Bentham yang telah mengembangkan pokok-pokok pikiran bidang hukum pidana serta menyatakan setiap kejahatan harus disertai dengan hukuman-hukuman yang sesuai dengan kejahatan tersebut untuk tujuan kebahagiaan dan mengurangi penderitaan bagi masyarakat. ${ }^{1}$

Salah satu contoh yang menggambarkan asas yang bertentangan terhadap nilai-nilai yang hidup dalam masyarakat Indonesia tertera pada asas legalitas formal. Asas tersebut berpandangan bahwa untuk menentukan patut tidaknya suatu perbuatan dianggap bersifat melawan hukum atau sebagai perbuatan pidana, harus didasarkan pada undang-undang atau peraturan tertulis saja, sehingga jika perbuatan tersebut tidak di atur dalam undang-undang tertulis, maka perbuatan tersebut tidak dapat dianggap sebagai perbuatan pidana, meskipun perasaan hukum atau nilai-nilai hukum masyarakat Indonesia memandang perbuatan tersebut sebagai perbuatan yang tidak patut, tercela ataupun bertentangan/melawan perasaan hukum (nilai-nilai) masyarakat Indonesia.

Keberadaan hukum adat sebagai hukum yang tumbuh dan hidup semenjak dahulu dalam masyarakat perlu mendapat perhatian yang cukup untuk penyelesaian suatu perkara pidana berdasarkan Pasal 28 Undang-Undang Nomor 48 Tahun 2009 tentang Kekuasaan Kehakiman ayat (1) menyebutkan bahwa, hakim wajib menggali, mengikuti, dan memahami nilai-nilai hukum dan rasa keadilan yang hidup dalam masyarakat.

Pengakuan atas hukum adat tertuang di berbagai peraturan perundangan, sehingga ini membuktikan bahwa eksistensi keberadaan hukum adat dalam hukum positif masih tetap dipertahankan meskipun ada beberapa hal tertentu hukum adat di batasi kewenangannya. Olehnya itu, kekosongan dalam hukum tertulis tidak harus dijadikan alasan hukum untuk tidak mengualifikasikan perbuatan perzinaan tersebut ke dalam perbuatan melawan hukum. Sebab, apapun alasannya perbuatan zina tersebut merupakan pelanggaran oleh aturan-aturan hukum tidak tertulis merupakan salah satu aturan yang diakui hidup pada masyarakat Indonesia sebagaimana telah disebutkan dalam ketentuan Pasal 5 ayat (3) sub b Undang-Undang Darurat Nomor 1 Tahun

\footnotetext{
${ }^{1}$ Soedjono Dirdjosisworo, Hukum Pidana Indonesia dan Gelagat Kriminalitas Masyarakat Pasca Industri, Sinar Grafika, Jakarta, 1991, h. 7.
}

1951 tentang Pemberlakuan Hukum Pidana Adat. Fleksibilitas seperti ini, diharapkan agar hukum agar benar-benar dapat digunakan sebagai instrumen untuk menciptakan keadilan di satu sisi (kebenaran realis), dan tidak mengenyampingkan kepastian hukum di sisi lain (kebenaran formalis), terlebih dalam hukum positif Indonesia mengakui bahwa salah satu sumber hukum formil adalah hukum adat (hukum kebiasaan).

Dalam masyarakat adat Tolaki mengatur masalah adat kalo sara yang merupakan perekat kekerabatan di antara masyarakat adat Tolaki, di mana kalo sara sebagai simbol dalam menyelesaikan permasalahan yang terjadi di dalam kehidupan masyarakat adat yang patut diterima dan dilaksanakan secara seksama, di mana dalam istilah dalam bahasa Tolaki yaitu inae kona sara iye pinesara, inae lia sara iye pinekasara, artinya siapa yang menghargai keberadaan adat dia akan dijunjung dengan baik dalam suatu adat, tetapi jika tidak menghargai suatu adat maka dia akan diperlakukan secara tidak baik (kasar). ${ }^{2}$

Salah satu tindak pidana yang diatur dalam hukum adat Tolaki adalah tindak pidana kesusilaan. Tindak pidana kesusilaan tidak jarang terjadi di tengah-tengah masyarakat, bahkan makin hari makin meningkat. Justru sekarang sudah merupakan istilah yang disebut selingkuh, hal ini dapat kita ketahui melalui pemberitaan mass media, baik yang bersifat nasional maupun yang bersifat lokal. Belum yang tidak terungkap secara luas yang bukannya hanya sering terjadi di kota-kota besar tetapi juga di kotakota kecil bahkan di pedesaan.

Keadilan yang diberikan oleh penerapan hukum melalui penjatuhan sanksi hukum, apalagi jika sanksi hukum yang dijatuhkan pada pelaku tidak adil atau tidak sesuai dengan akibat yang ditimbulkannya. Ketidakadilan hukum inilah yang disebut dapat menjauhkan masyarakat yang tertimpa musibah (menjadi korban suatu tindak pidana) untuk bersedia berurusan dengan dunia peradilan.

Sudah merupakan kelaziman bahwa setiap pelaku tindak pidana kesusilaan akan mendapatkan konsekuensi hukuman. Tindak pidana persetubuhan yang diuraikan di dalam pasal-pasal KUHP seperti overspel atau zina, pemerkosaan, perbuatan cabul, pelecehan seksual, dan lain-lain belum dapat menjangkau konsep persetubuhan atau perzinahan

\footnotetext{
${ }^{2}$ Abd. Latif Parase Hatubi selaku Petua Adat, Isi Lokakarya Unifikasi Hukum Adat Sarano Tolaki, Kendari, 2006, h. 12.
} 
yang terdapat di dalam hukum adat khususnya hukum adat Tolaki di Sulawesi Tenggara.

Sanksi yang diterapkan terhadap pelaku tindak pidana kesusilaan menurut hukum adat Tolaki terbagi menjadi 2 yaitu peohala dan pinakawi. Sanksi peohala yaitu pemberian ganti kerugian berupa uang, sarung dan kain kafan beserta isi-isi adat lainnya yang diberikan kepada pelaku tindak pidana kesusilaan ringan seperti pencabulan, pelecehan seksual. Sanksi pinakawi yaitu pernikahan yang dilakukan karena adanya pelanggaran adat yang dianggap melanggar norma-norma hukum adat dan hukum Islam yang diberikan kepada pelaku tindak pidana seksual berat seperti tindak pidana pemerkosaan, dan perzinahan.

Hukum adat Tolaki istilah perzinahan disebut dengan Umoapi. Di dalam KUHP perbuatan zina diatur pada Pasal 284 KUHP yang mengatur pada perbuatan persetubuhan yang salah satu atau keduanya telah terikat dengan perkawinan. Sedangkan dalam hukum adat Tolaki istilah zina atau umoapi lebih mengatur secara kompleks tentang perbuatan zina yang tidak hanya sebatas pada status perkawinan dengan klasifikasi dan sanksi yang berbeda berdasarkan tingkatan umoapi yang dilakukan.

Adapun rumusan masalah dalam jurnal penelitian ini adalah Bagaimanakah Pemidanaan Delik Perzinahan atau Persetubuhan (Umoapi) dalam Perspektif Hukum Pidana Adat Tolaki di Sulawesi Tenggara?

\section{METODE PENELITIAN}

Tipe penelitian yang digunakan dalam penelitian ini adalah normatif yaitu dengan menganalisis data yang mengacu pada norma-norma hukum yang dituangkan dalam peraturan perundang-undangan khususnya yang berkaitan dengan judul yang penulis angkat.

Pendekatan-pendekatan yang digunakan dalam penelitian hukum normatif adalah pendekatan undangundang atau statute approach dilakukan dengan menelaah semua undang-undang dan regulasi yang berhubungan dengan judul yang diteliti, pendekatan kasus dilakukan terhadap kasus-kasus yang berkaitan dengan isu hukum yang dihadapi yang telah menjadi putusan pengadilan yang telah mempunyai kekuatan hukum yang tetap, pendekatan ini dilakukan dengan membandingkan undang-undang suatu negara dengan undang-undang dari satu atau lebih negara lain mengenai hal yang sama. Dapat juga yang diperbandingkan di samping undang-undang juga putusan pengadilan di beberapa negara untuk kasus yang sama dan pendekatan konseptual beranjak dari pandangan-pandangan dan doktrin-doktrin yang berkembang dalam ilmu hukum.

Jenis dan sumber bahan hukum yang digunakan adalah bahan hukum primer adalah bahan hukum yang terdiri dari perundang-undangan, catatan-catatan resmi atau risalah dalam pembuatan undang-undang dan bahan hukum sekunder adalah bahan hukum berupa semua publikasi tentang hukum yang bukan merupakan dokumen-dokumen resmi.

\section{PEMBAHASAN}

\section{Asas Legalitas dalam Hukum Pidana}

Salah satu asas yang menjadi landasan hukum keberlakuan KUHP yang juga merupakan landasan tujuan hukum secara umum dicantumkan di dalamnya guna memberikan rasa keadilan bagi warga negara, antara lain yaitu asas legalitas atau nullum delictum nulla poena sine lege poenalle yang sudah secara tegas dirumuskan dalam ketentuan Pasal 1 ayat (1) KUHP sebagai pandangan bagi hukum pidana yang mengandung makna:

Pertama, Tidak ada perbuatan yang dilarang dan diancam dengan pidana apabila hal itu terlebih dahulu belum dinyatakan dalam suatu aturan undang-undang. Artinya bahwa untuk mengatakan bahwa perbuatan tersebut patut atau tidaknya dikatakan perbuatan melawan hukum apabila telah diatur undang-undang tersebut.

Kedua, Untuk menentukan ada tidaknya perbuatan pidana tidak boleh digunakan analogi atau qiyas. Artinya bahwa salah satu konsekuensi dianutnya asas legalitas formal dalam Pasal 1 ayat (1) KUHP adalah larangan untuk tidak menggunakan analogi dalam menentukan ada tidaknya suatu perbuatan melawan hukum.

Ketiga, Larangan berlaku surutnya aturan pidana atau asas non retroaktif. Larangan berlaku surutnya aturan pidana hakikatnya sangat logis tertera dalam asas legalitas, berhubung adanya ketentuan, bahwa tidak seorang pun dapat dijatuhi pidana kecuali atas kekuatan aturan pidana yang sudah ada sebelum perbuatan dilakukan. Jadi prinsip ini juga mengandung pengertian, bahwa undang-undang itu hanya berlaku untuk hal-hal yang terjadi kemudian. Dominasi positivisme dalam hukum pidana Indonesia merupakan alasan negara dalam hal memberikan 
kepastian hukum serta rasa keadilan bagi setiap warga negara.

Bertolak dari kenyataan, bahwa prinsip atau asas legalitas yang dianut hukum pidana yang sekarang berlaku atau KUHP kurang cocok dalam tradisi hukum masyarakat, maka rumusan asas legalitas dalam rancangan KUHP baru itu dimaksudkan untuk mewujudkan nilai-nilai yang berlaku dalam masyarakat Indonesia. Secara tegas rumusan tentang asas legalitas dalam rancangan KUHP Baru Tahun 2004 dirumuskan dalam Pasal 1 yang naskah lengkapnya sebagai berikut: Pertama, Tiada seorang pun dapat di pidana atau dikenakan tindakan kecuali perbuatan yang dilakukannya telah ditetapkan sebagai tindak pidana dalam peraturan perundang-undangan yang berlaku pada saat perbuatan itu dilakukan; Kedua, Dalam menetapkan adanya tindak pidana dilarang menggunakan analogi; Ketiga, Ketentuan dalam ayat (1) tidak mengurangi berlakunya hukum yang hidup yang menentukan bahwa menurut adat setempat seseorang patut di pidana walaupun perbuatan itu tidak diatur dalam peraturan perundangundangan; Keempat, Berlakunya hukum yang hidup dalam masyarakat sebagaimana dimaksud dalam ayat (3) sepanjang sesuai dengan nilai-nilai Pancasila dan/ atau prinsip-prinsip hukum umum yang diakui oleh masyarakat bangsa-bangsa.

D.H. Suringa menyatakan, bahwa sumber utama tentang berlakunya undang-undang hukum pidana menurut waktu, tersimpul di dalam Pasal 1 ayat (1) KUHP antara lain: Pertama, Mempunyai makna nullum delictum, nulla poena sine praevia lege poenale yaitu tiada delik, tiada pidana, tanpa peraturan yang mengancam pidana lebih dahulu. Kedua, Mempunyai makna undang-undang hukum pidana tidak mempunyai kekuatan berlaku surut. Ketiga, Mempunyai makna lex temporis delicti, yang artinya undang-undang berlaku terhadap delik yang terjadi pada saat itu. ${ }^{3}$

Menurut Moeljatno, bahwa asas legalitas mengandung tiga pengertian yaitu: Pertama, Tidak ada perbuatan yang dilarang dan diancam dengan pidana kalau hal itu terlebih dahulu belum dinyatakan dalam suatu aturan undang-undang; Kedua, Untuk menentukan adanya perbuatan pidana tidak boleh

\footnotetext{
${ }^{3}$ Bambang Poernomo, Seri Hukum Pidana I Asas-asas Hukum Pidana, Ghalia Indonesia, Jakarta, 1992, h. 68.
}

digunakan analogi; Ketiga, Aturan-aturan hukum pidana tidak boleh berlaku surut. ${ }^{4}$

Menurut Tongat, terdapat dua prinsip dasar atau asas-asas yang dapat digunakan sebagai dasar untuk menentukan patut tidaknya suatu perbuatan dianggap bersifat melawan hukum atau sebagai perbuatan pidana, yaitu: ${ }^{5}$

Pertama, Asas legalitas formal, yang sudah dirumuskan secara eksplisit dalam Pasal 1 ayat (1) KUHP. Asas ini menggariskan bahwa dasar untuk patut tidaknya suatu perbuatan dapat dikualifikasikan sebagai perbuatan melawan hukum atau perbuatan pidana, sehingga karenanya dapat dipidana, adalah ketentuan dalam undang-undang yang harus sudah ada sebelum perbuatan itu dilakukan.

Kedua, Asas legalitas materiil, prinsip ini tidak dirumuskan secara formal dalam KUHP, tetapi prinsip ini tetap hidup dan dipegang teguh oleh masyarakat. Asas legalitas materil menggariskan, bahwa dasar untuk menentukan patut tidaknya suatu perbuatan dianggap bersifat melawan hukum atau perbuatan pidana adalah nilai-nilai yang hidup dalam masyarakat atau living law. Nilai-nilai yang hidup dalam masyarakat tersebut adalah nilai-nilai moral, nilai-nilai agama, nilai-nilai adat, dan sebagainya.

\section{Pengertian Hukum Pidana Adat}

Hazairin memberikan suatu uraian yang relatif panjang mengenai masyarakat hukum adat adalah kesatuan-kesatuan kemasyarakatan yang mempunyai kelengkapan-kelengkapan untuk sanggup berdiri sendiri yaitu mempunyai kesatuan hukum, kesatuan penguasa dan kesatuan lingkungan hidup berdasarkan hak bersama atas tanah dan air bagi semua anggotanya. ${ }^{6}$

Masyarakat hukum adat yang susunannya didasarkan atas pertalian keturunan menurut garis laki-laki, masyarakat hukum adat kebapaan atau patrilenear, seperti halnya dengan masyarakat hukum adat yang susunannya didasarkan atas pertalian keturunan menurut garis perempuan masyarakat hukum adat keibuan atau matrilenear. ${ }^{7}$

\footnotetext{
${ }^{4}$ Moeljatno, 1985, h. 25.

5 Tongat, Asas-Asas Hukum Adat, Pembangunan, Jakarta, 2009, h. 51-52.

${ }^{6}$ Soerjono Soekanto, Hukum Adat Indonesia, Raja Grafindo Persada, Jakarta, 2005, h. 95

7 Muhammad Bushar, Asas-asas Hukum Adat Suatu Pengantar, Pradnya Paramita, Jakarta, 2006, h. 19.
} 
Beberapa ciri pokok masyarakat hukum adat adalah mereka merupakan suatu kelompok manusia yang mempunyai kekayaan sendiri terlepas dari kekayaan perorangan serta memiliki batas wilayah tertentu serta kewenangan tertentu. Dengan demikian hak tanah ulayat menunjukkan hubungan hukum antara masyarakat hukum atau subyek hak dan tanah atau wilayah tertentu atau obyek hak. ${ }^{8}$

Untuk memberikan gambaran yang lebih utuh tentang perbuatan tindak pidana, berikut ini dikemukakan batasan atau pengertian tindak pidana menurut hukum adat. Sajian dalam konteks ini dipandang sangat penting, lebih-lebih apabila disadari, bahwa gagasan atau ide tentang living law mulai mengedepan seiring dengan adanya upaya pembaharuan hukum pidana nasional yang ingin menempatkan hukum adat sebagai sumber hukum pidana nasional. Bertolak dari pemikiran seperti ini, pemahaaman terhadap batasan/pengertian tindak pidana menurut hukum adat menjadi sebuah keharusan. ${ }^{9}$

Menurut Bushar Muhammad bahwa delik adat adalah setiap perbuatan sepihak dari sepihak atau kumpulan perorangan, mengancam atau menyinggung atau mengganggu keseimbangan dalam kehidupan persekutuan, bersifat materiil atau immateriil, terhadap orang seorang atau terhadap masyarakat berupa kesatuan, tindakan atau perbuatan yang demikian mengakibatkan suatu reaksi adat yang dipercayainya dapat memulihkan keseimbangan yang telah terganggu, antara lain dengan berbagai jalan dan cara, dengan pembayaran adat berupa barang, uang, mengadakan selamatan, memotong hewan besar/ kecil dan lain-lain. ${ }^{10}$

Menurut Soebekti Poeponoto bahwa tindak pidana atau delik adat adalah setiap gangguan segi satu terhadap keseimbangan dan setiap penubrukan dari segi satu pada barang-barang kehidupan materiil dan imateriil orang-orang, atau dari pada orang-orang banyak yang merupakan satu kesatuan (segerombolan); tindakan sedemikian itu menimbulkan suatu reaksi yang sifatnya dan besar kecilnya ditetapkan oleh hukum adat -ialah reaksi

${ }^{8}$ Sihombing, Pengantar Hukum Adat Indonesia, Toko Gunung Agung, Jakarta, 2007, h. 56.

${ }^{9}$ Tongat, Asas-Asas Hukum Adat, Pembangunan, Jakarta, 2009, h. 110.

${ }^{10}$ Muhammad Bushar, Asas-asas Hukum Adat Suatu Pengantar, Pradnya Paramita, Jakarta, 2006, h. 61-62. adat- karena reaksi mana ada keseimbangan dapat dan harus dipulihkan kembali. ${ }^{11}$

Berdasarkan batasan-batasan tersebut di atas, maka dapat disimpulkan bahwa delik adat memuat unsur-unsur sebagai berikut: Perbuatan sepihak dari seorang atau kumpulan perorangan; Perbuatan tersebut mengganggu keseimbangan persekutuan/ masyarakat; Perbuatan tersebut bersifat materiil dan immateriil; Perbuatan tersebut ditujukan terhadap orang seorang atau masyarakat; Mengakibatkan reaksi adat. ${ }^{12}$

\section{Konsep Tindak Pidana Kesusilaan}

Tindak pidana terhadap kesusilaan pada umumnya menimbulkan kekhawatiran/kecemasan khususnya orangtua terhadap anak wanita karena selain dapat mengancam keselamatan anak-anak wanita (misalnya perkosaan, perbuatan cabul) dapat pula mempengaruhi proses ke arah kedewasaan seksual lebih dini.

Tindak pidana ini paling banyak menimbulkan kesulitan dalam penyelesaiannya baik pada tahap penyidikan, penuntutan, maupun pada tahap pengambilan keputusan. Selain kesulitan dalam batasan juga kesulitan pembuktian misalnya perkosaan atau pun perbuatan cabul yang pada umumnya dilakukan tanpa kehadiran orang lain.

Menurut van Bemmelen menyatakan bahwa delik terhadap kesusilaan tidak hanya memuat berbagai tindak pidana kesusilaan, akan tetapi juga beberapa delik yang sama sekali tidak ada sangkut pautnya dengan seksualitas: memberi minuman yang memabukkan kepada orang atau anak di bawah enam belas tahun yang sudah kelihatan mabuk, menyerahkan atau membiarkan anak yang ada dalam kekuasannya kepada orang lain, padahal mengetahui bahwa anak itu akan dipakai untuk atau pada waktu mengemis, penganiayaan binatang, selanjutnya memuat abortus provocatus. ${ }^{13}$ Dalam prinsip ini tidak tepat penempatan delik-delik tersebut.

Menurut Kamus Besar Bahasa Indonesia bahwa: Perzinahan berasal dari kata zina yang berarti perbuatan bersenggama antara laki-laki dan perempuan yang

11 Poeponoto Soebekti, Bab-bab tentang Hukum Adat, Djambatan, Jakarta, 1980, h. 255.

${ }^{12}$ Tongat, Asas-Asas Hukum Adat, Pembangunan, Jakarta, 2009, h. 110.

${ }^{13}$ Leden Marpaung, Kejahatan terhadap Kesusilaan dan Masalah Prevensinya, Sinar Grafika, Jakarta, 2004, h. 31. 
tidak terikat oleh hubungan pernikahan dan zina merupakan perbuatan bersenggama seorang laki-laki yang terikat perkawinan dengan seorang perempuan yang terikat perkawinan dengan seorang laki-laki yang bukan suaminya. ${ }^{14}$

Zina merupakan persetubuhan yang dilakukan oleh laki-laki atau perempuan yang telah kawin dengan perempuan atau laki-laki yang bukan isteri atau suaminya. Supaya masuk pasal ini, maka persetubuhan itu harus dilakukan suka sama suka, tidak boleh ada paksaan dari salah satu pihak. Persetubuhan merupakan masuknya alat kelamin laki-laki dengan alat kelamin perempuan yang biasa dijalankan untuk mendapatkan anak, jadi anggota laki-laki harus masuk ke dalam anggota perempuan, sehingga mengeluarkan air mani. ${ }^{15}$ Zina merupakan persetubuhan yang dilakukan oleh lakilaki atau perempuan yang telah kawin. Dikatakan ada persetubuhan apabila anggota kelamin laki-laki masuk ke dalam kelamin perempuan. ${ }^{16}$

Sedangkan menurut Marzuki Umar Sa'abah bahwa perzinahan merupakan hubungan seks yang dilakukan seseorang yang telah menjalin pernikahan dengan orang lain yang bukan pasangan sahnya. ${ }^{17}$ Menurut Hamdani bahwa, yaitu adanya perpaduan antara alat kelamin laki-laki dengan alat kelamin perempuan dengan penetrasi yang agak ringan yaitu dengan atau tanpa mengeluarkan air mani. ${ }^{18}$ Menurut Noerwahidah bahwa zina adalah persetubuhan yang dilakukan oleh seorang laki-laki dengan seorang perempuan atas kehendak bersama tanpa melalui perkawinan yang sah. ${ }^{19}$

Tindak pidana perzinahan diatur dalam Pasal 284 KUHP bahwa:

Pertama, Dihukum dengan hukuman penjara selama-lamanya sembilan bulan: Ke-1: a. Orang laki-laki yang sudah kawin, yang melakukan zina sedang diketahui, bahwa Pasal Kitab Undang-Undang Hukum Perdata (KUHPerdata) berlaku baginya; b. Orang perempuan yang sudah kawin, yang melakukan

\footnotetext{
${ }^{14}$ Departemen Pendidikan dan Kebudayaan, Kamus Besar Bahasa Indonesia, Balai Pustaka, Jakarta, 2005, h. 1280.

15 Sesuai dengan Arrest Hooge Raad 5 Februari 1912 (W. 9292), Soesilo, 1995, h. 209.

${ }^{16}$ Soegandhi, Kejahatan terhadap Kesusilaan, Bina Aksara, Jakarta, 2000, h. 30.

${ }^{17}$ Marzuki Umar Sa'abah, Seks \& Kita, Gema Insani Press, Jakarta, 1997, h. 129.

${ }^{18}$ Hamdani, 1974, h. 201.

${ }^{19}$ Noerwahidah, 1993, h. 45.
}

zina; Ke-2: a. Orang laki-laki yang turut melakukan zina itu, sedang diketahui, bahwa yang turut bersalah, sudah bersuami; b. Orang perempuan yang tidak bersuami, yang turut melakukan zina itu, sedang diketahui bahwa yang turut bersalah sudah beristri dan Pasal 27 KUHPerdata berlaku baginya.

Kedua, Tidak dilakukan penuntutan, kecuali atas pengaduan suami/istri yang terhina dan, dalam bagi suami/istri berlaku Pasal 27 KUHPerdata jika dalam tempo tiga bulan sesudah pengaduan ini ia memasukkan gugatan untuk bercerai atau agar dibebaskan dari kewajiban berdiam bersama oleh karena hal itu juga.

Ketiga, Atas pengaduan ini tidak berlaku Pasal 72, 73, dan Pasal 75 KUHP.

Keempat, Pengaduan ini dapat ditarik kembali selama pemeriksaan di muka pengadilan belum dimulai.

Kelima, Jika atas suami/istri itu berlaku Pasal 27 KUHPerdata, maka pengaduan itu tidak diindahkan sebelum perkawinan diputuskan karena perceraian atau sebelum keputusan yang membebaskan mereka dari kewajiban berdiam bersama menjadi tetap.

Pengertian zina menurut Pasal 284 KUHP yang diisyaratkan harus laki-laki atau perempuan yang sedang kawin, berlatar belakang pada pemikiran orangorang Belanda bahwa zina itu sebagai pengingkaran perkawinan, yang berbeda menurut hukum adat yang berlatar belakang penodaan nilai-nilai kesucian daripada persetubuhan. Menurut hukum adat di dalam persetubuhan itu terkandung nilai-nilai kesucian. Oleh karena itu, untuk melakukannya diperlukan syarat, yaitu perkawinan. Apabila dilakukan di luar perkawinan, dia berdosa dan telah melanggar nilai kesucian itu, dia berzina, oleh sebab itu si pembuatnya harus dihukum. ${ }^{20}$

Dalam pasal ini dibedakan antara mereka yang tunduk pada Pasal 27 KUHPerdata ialah orang Eropa dan yang disamakan dengan mereka dan mereka yang tunduk pada pasal itu (orang yang beragama Islam, dan sebagainya). Pasal 27 KUHPerdata mengatakan, bahwa orang laki-laki hanya boleh menikah dengan seorang laki-laki bersamaan. Mereka yang tunduk pada pasal ini, baik laki-laki maupun perempuannya tidak boleh bersetubuh dengan orang lain, selain dengan isteri atau suaminya sendiri. Menurut hukum adat dari banyak daerah Indonesia, maka perzinahan

\footnotetext{
${ }^{20}$ Ledeng Marpaung, Kejahatan terhadap Kesusilaan dan Masalah Prevensinya, Sinar Grafika, Jakarta, 2004, h. 56.
} 
hanya dapat dilakukan oleh si isteri dipandang sebagai melanggar hak suami. Bila tertangkap tangan, maka menurut hukum adat itu si suami malahan berhak untuk membunuh isterinya dan laki-laki lain yang sedang berzina itu. Dikalangan Islam pun perzinahan itu hanya dapat dilakukan oleh si isteri, laki-laki tidak mungkin karena agama Islam membolehkan poligami. ${ }^{21}$

Pasal di atas dijelaskan oleh Wirjono Prodjodikoro, bahwa bukan hanya orang Islam yang tunduk pada pasal ini tetapi juga orang Kristen tunduk pada peraturan ini, bahwa tindak pidana zina hanya dapat dilakukan oleh seorang istri, tidak boleh seorang laki-laki/suami karena mereka takluk pada peraturan monogami. 22

Menurut Sugandhi makna dari Pasal 284 ini ialah bahwa hanya pelaku persetubuhan yang sudah terikat perkawinan yang dapat disebut sebagai pezina atau pengendak. Jika keduanya sudah terikat perkawinan, maka keduanya adalah pezina. Jika salah satu saja yang sudah terikat perkawinan, maka yang belum/ tidak terikat itu disebut sebagai peserta pezina saja, dan jika keduanya belum/tidak terikat itu disebut sebagai peserta pezina saja, dan jika keduanya belum/ tidak terikat suatu perkawinan, maka tidak ada pezina di antara mereka

\section{Pemidanaan Delik Perzinahan/Persetubuhan atau Umoapi dalam Perspektif Hukum Pidana Adat Tolaki di Sulawesi Tenggara}

Suku Tolaki merupakan salah satu di antara penduduk asli terbesar yang menempati wilayah Propinsi Sulawesi Tenggara, selain Suku Muna di Pulau Muna dan Buton di Pulau Buton. Kelompok etnis terbesar ini berasal dari 2 kerajaan yang masih bersaudara yaitu Kerajaan Konawe dan Mekongga. Kerajaan Konawe pusatnya berada di Kecamatan Unaaha Kabupaten Konawe sekarang dan Kerajaan Mekongga dalam wilayahnya meliputi Kabupaten Kolaka. Kedua suku tersebut memiliki budaya dan bahasa yang hampir sama.

Mengenai asal usul persebaran Suku Tolaki, Tarimana dalam disertasinya menduga bahwa orang Tolaki itu asal usulnya dari arah utara dan timur yang datang ke Sulawesi Tenggara. Mereka yang datang dari arah utara itu berasal dari Tiongkok

\footnotetext{
21 Soesilo, 1995, h. 209.

22 Wirjono Prodjodikoro, Azas-azas Hukum Pidana Indonesia, Refika Aditama, Bandung, 2003, h. 123.
}

Selatan melalui Philipina, Kepulauan Mindanau, Sulawesi Utara, Halmahera dan Sulawesi bagian timur terus memasuki muara Sungai Lasolo atau Sungai Konawe'eha yang akhirnya memilih lokasi pemukiman pertama di hulu sungai, yakni pada suatu lembah yang luas, yang dinamakan Andolaki. ${ }^{23}$

Orang Tolaki pada mulanya menamakan dirinya Tolahiangga atau orang dari langit, mungkin yang dimaksudkan dengan istilah langit adalah kerajaan langit, yakni Cina, hal itu dimungkinkan dari dari kata Hiu yang dalam Bahasa Cina berarti Langit, dihubungkan dengan kata $\mathrm{Heo}$ atau Tolaki yang berarti ikut pergi ke langit. Mereka yang datang dari arah selatan dimungkinkan berasal dari Pulau Jawa melalui Buton dan Muna dan memasuki muara Sungai Konaweeha dan terus memilih lokasi pemukiman di Toreo, Landono, dan Besulutu.

Menurut cerita mitologi yang berkembang di kalangan orang Tolaki dahulu pernah berdiri dua kerajaan, yaitu Kerajaan Konawe dan Kerajaan Mekongga, masing-masing didirikan oleh dua bersaudara kakak adik, yaitu Larumbalangi dan Wekoila. Pusat Kerajaan Konawe mula-mula berlokasi di Desa Olo-oloho di pinggir Sungai Konaweeha di Desa Uepai yang sekarang, kemudian pindah ke Unaaha. Adapun Kerajaan Mekongga, mula-mula berlokasi di Bende, kemudian pindah di Wundulako, Kabupaten Kolaka mula-mula raja Bergelar Mokole kemudian untuk Raja Mekongga, gelar itu berubah menjadi Bokeo.

Dari Desa Andolaki inilah orang Tolaki kemudian terpencar ke utara sampai Routa, ke barat sampai Kodeeha lewat Mowewe dan Lambo, kemudian ada yang sampai di Mekongga, ke selatan sampai di Olooloho atau Konawe lewat Ambekairi dan Asinua, dan ke timur sampai Latoma dan Asera. Orang Tolaki yang bermukim pertama di Landono dan Besulutu kemudian menyebar ke wilayah sebelah Timur meliputi wilayah muara Sungai Konaweeha dan Sungai Lasolo. Ke wilayah Selatan di Pu'unggaluku, Tinanggea, Kolono, dan Moramo, ada juga yang menyeberang ke Pulau Wawoni'i. ${ }^{24}$

Orang Tolaki yang berdiam di Wilayah Kerajaan Mekongga Kabupaten Kolaka sekarang menamakan dirinya orang Mekongga, dan mereka yang berdiam

\footnotetext{
${ }^{23}$ Abdul Rauf Tarimana, Kebudayaan Tolaki, Balai Pustaka, Jakarta, 1993, h. 51.

${ }^{24}$ Pingak dalam Abdul Rauf Tarimana, Kebudayaan Tolaki, Balai Pustaka, Jakarta, 1993.
} 
di wilayah Kerajaan Konawe, yakni bagian wilayah Kabupaten Konawe sekarang, menamakan dirinya orang Konawe.

Berdasarkan uraian-uraian di atas, maka dapatlah dikatakan bahwa masyarakat Suku Tolaki telah menyebar di seluruh Sulawesi Tenggara dan komunitas yang paling banyak dari suku Tolaki adalah mereka yang bertempat tinggal di wilayah Kabupaten Konawe, Kabupaten Konawe Selatan dan Kota Kendari. Penyebaran masyarakat suku Tolaki di beberapa wilayah yang terdapat di Sulawesi Tenggara menunjukkan bahwa masyarakat Suku Tolaki tidak lagi hanya bertempat tinggal di desa-desa, tetapi juga tinggal di daerah perkotaan.

Walaupun dalam penyebarannya ke berbagai wilayah, masyarakat suku Tolaki tetap mempertahankan kebiasaan-kebiasaan maupun adat istiadatnya dalam pergaulan hidupnya di masyarakat, sehingga adat-istiadat dari suku Tolaki tersebut tetap terjaga dan lestari sepanjang masa. Oleh karena, masyarakat suku Tolaki masih mempercayai dan menyakini bahwa adat istiadat yang terangkum dalam Kalo Sara adalah merupakan suatu pedoman hidup yang tidak boleh dilanggar atau dikesampingkan sama sekali. Sebab bagi siapa yang melanggar dari Kalo Sara yang telah dipercayai sejak turun temurun maka orang tersebut akan mendapatkan bala atau musibah.

Untuk memperkuat analisis ini maka penulis merujuk pada pendapat Barda Nawawi Arif dalam Diktat Ajar Didik Endro Purwoleksono yang mengemukakan bahwa pertanggungjawaban pidana, diarahkan pada masalah dapat atau tidak dapat dipidananya pelaku tindak pidana. Tepat sekali apa yang diungkapkan oleh Barda Nawawi Arief, bahwa masalah pertanggunjawaban pidana dititikberatkan kepada adanya perbuatan yang tercela secara objektif maupun tercela secara subjektif. Pencelaan secara obyektiif maupun pencelaan secara subyektif, hal ini juga sudah diadopsi dalam Pasal 64 RUU KUHP.

Makna pencelaan secara objektif, parameternya atau ukurannya adalah adanya norma larangan maupun norma kaharusan dalam UU, perbuatan, kegiatan atau aktivitas memang patut dicela.

Pencelaan secara subkjektif, diarahkan kepada pelakunya bahwa dia patut di pidana. Asas yang mendasari pertanggungjawaban pidana merupakan asas kesalahan geen straf zonder schuld atau tiada pidana tanpa kesalahan. Dengan perkataan lain, masalah pertanggunjawaban pidana, diarahkan kepada pembahasan tentang dapat atau tidak dapat dipidananya pelaku tindak pidana.

Tidak kalah pentingnya ciri khas hukum pidana, yang membedakan dengan hukum lain, yaitu adanya sanksi yang berupa sanksi pidana. Pidana itu sendiri dari berbagai pandangan para pakar, merupakan suatu nestapa, derita, ketidakenakan, ketidaknyamanan, pengekangan hak-hak seseorang, yang dijatuhkan oleh hakim kepada seseorang yang telah terbukti secara sah dan menyakinkan telah melakukan tindak pidana. Hukum pidana sengaja memberikan penderitaan dalam mempertahankan norma-norma yang diakui dalam hukum.

Pendapat Barda Nawawi Arif tersebut mengisyaratkan penulis bahwa suatu perbuatan pidana tidak harus dirumuskan secara implisit di dalam undang-undang karena undang-undang memiliki keterbatasan untuk mengaturnya karena perkembangan manusia yang cenderung dinamis yang diikuti dengan perkembangan tindak pidana, untuk itu perbuatan seseorang dapat bertanggungjawab secara hukum ukurannya merupakan perbuatan tersebut tercela atau tidak oleh masyarakat dan oleh masyarakat perbuatan tersebut dapat di pidana menurut hukum yang ada di dalam masyarakat dalam hal ini hukum tertulis dan tidak tertulis. Oleh karenanya penyelesaian melalui hukum adat terhadap tindak pidana persetubuhan merupakan hal yang patut dihormati dan dihargai oleh para penegak hukum karena hukum adat memiliki dasar hukum keberlakuan dan mengikat bagi masyarakat.

Pelanggaran hukum adat yang dilakukan oleh seseorang terhadap orang lain terhadap beberapa pelanggaran hukum yang berlaku di masyarakat, petugas hukum adat hanya bertindak jika diminta oleh orang yang merasa dirugikan kepentingannya. Sedangkan terhadap tindakan-tindakan hukum lainnya, petugas hukum adat dapat bertindak atas inisiatif sendiri bilamana petugas tersebut menemukan atau mendapat secara langsung warganya melakukan pelanggaran atau ketentuan-ketentuan hukum adat yang berlaku di wilayahnya. Ukuran yang dipakai hukum adat untuk menentukan dalam hal mana para petugas hukum harus bertindak dan dalam hal mana mereka hanya akan bertindak atas permintaan orang yang berkepentingan.

Tiap-tiap pelanggaran hukum, para petugas hukum menimbang bagaimana mereka akan bertindak untuk membetulkan kembali keseimbangan hukum. 
Tindakan atau pertahanan adat yang diperlukan mungkin hanya berupa hukuman denda yaitu berupa membayar sejumlah uang sebagai denda adat (pengganti kerugian) atas perbuatan yang dilakukan seseorang terhadap pelanggaran adat yang dilakukan dalam hal ini pelanggaran terhadap tindak pidana persetubuhan dan ini pula yang dikenal dalam hukum adat Tolaki. Untuk dapat dimintakan pertanggungjawaban hukum Pelanggaran terhadap delik adat, maka perbuatan tersebut harus dapat memenuhi unsur-unsur sebagai berikut: Perbuatan sepihak dari seorang atau kumpulan perorangan; Perbuatan tersebut mengganggu keseimbangan persekutuan atau masyarakat; Perbuatan tersebut bersifat materiil dan immateriil; Perbuatan tersebut ditujukan terhadap orang seorang atau masyarakat; Mengakibatkan reaksi adat.

Dengan unsur-unsur seperti tersebut di atas terlihat, bahwa delik adat merupakan setiap perbuatan dari seseorang atau kumpulan orang (badan hukum) baik bersifat materiil atau immateriil yang ditujukan terhadap orang atau perkumpulan orang yang menimbulkan gangguan keseimbangan masyarakat dan menimbulkan reaksi adat. Dalam konteks hukum adat tindak pidana (delik adat) tidak saja meliputi setiap perbuatan yang dapat menimbulkan kerusakan individual tetapi juga setiap perbuatan yang dapat menimbulkan kerusakan sosial.

Lembaga adat Kalo Sara di dalam menyelesaikan perbuatan melawan hukum (tindak pidana adat Kalo Sara) yang terjadi pada Masyarakat Tolaki mengatur tentang tindak pidana persetubuhan yang di dalam pengaturan pula menguraikan tentang pemberian denda adat yang akan diberikan kepada korban sesuai dengan jenis tindak pidana adat yang dilakukan.

Menurut hukum adat Suku Tolaki apabila ada yang melakukan persetubuhan, maka yang menanggung malu dari akibat persetubuhan tersebut adalah keluarga pihak perempuan sehingga menurut hukum adat maka yang dikenakan sanksi atau denda adalah pihak laki-laki. Mengenai bentuk persetubuhan serta sanksi yang dikenal oleh masyarakat Suku Tolaki yang di tentukan oleh lembaga adat Kalo Sara kepada korban.

Delik umoapi yang terjadi di masyarakat suku Tolaki pada umumnya disebabkan oleh berbagai faktor yang dapat menimbulkan masalah hukum dan masalah sosial yang dapat mengganggu keseimbangan dan keharmonisan hidup bermasyarakat. Perbuatan delik umoapi itu sendiri merupakan perbuatan yang sangat dicela oleh masyarakat, karena telah menodai ajaran Kalo Sara, sehingga masyarakat mengganggap bahwa orang yang melakukan hal tersebut adalah manusia yang tidak mempunyai harga diri dan manusia yang tidak tahu malu. Dan pelakunya harus dibunuh, untuk menghindari terjadinya pembunuhan tersebut maka pihak yang melakukan tindak pidana, meminta perlindungan hukum pada salah satu tokoh adat Kalo Sara. Dengan demikian maka penyelesaiannya dilakukan oleh lembaga adat Kalo Sara. Dalam hukum adat Tolaki membagi klasifikasi umoapi atau persetubuhan menjadi dua bagian yaitu persetubuhan dengan pemberatan atau umoapi owose dan persetubuhan biasa atau umoapi mohewu.

Perzinahan dengan Pemberatan atau umoapi owose yang di atur dalam hukum pidana adat Tolaki, sebagai hukum yang ditaati dan dipatuhi oleh masyarakat Tolaki di Sulawesi tenggara. Salah satu perbuatan yang diatur dalam hukum adat Tolaki adalah perbuatan persetubuhanan yang dalam bahasa Tolaki disebut Umoapi Wali atau Persetubuhan Istri Orang, Umoapi sarapu atau Persetubuhan Tunangan Orang. Perbuatan persetubuhan tersebut merupakan suatu perbutan yang melanggar hukum dan perbuatan tersebut dalam kaca mata hukum adat Tolaki merupakan perbuatan yang masuk dalam klasifikasi tindak pidana adat dengan pemberatan.

Perzinahan terhadap Istri Orang atau Umoapi Wali, terdapat dua tipe yaitu sebagai berikut:

Pertama, Wali Ngginopukopu atau istri yang masih dipelihara oleh suami. Umoapi seperti ini merupakan tindak pidana delik hukum pidana adat Tolaki yang tertinggi yang bisa berakhir pada pembunuhan baik laki-laki yang merampas atau bisa juga dengan istri yang dirampas. Peran tokoh adat dan pelaku adat dituntut kebolehannya melakukan pendekatan jika laki-laki yang dirampas istrinya atau korban bersedia menerima cara penyelesaian secara adat, maka hukum adat Tolaki membolehkannya dengan cara: Kepada pihak atau korban dilakukan pengajuan adat mowea owose atau pelepas adat besar yaitu: a) Pihak perampas harus membayar 1 ekor kerbau hidup sebagai pengganti kerbau kurban yang dipotong saat pesta pernikahan dengan istrinya dahulu pesta atau tidak tetapi jika adat perkawinannya atau niwindahako sudah diselesaikan, kategorinya dianggap hal tersebut mutlak dipenuhi; b) Pihak perampas harus memberikan 1 buah parang atau 
opade sebagai penyerahan atas kehormatan pelaku; c) Jika suami belum membayar adat perkawinannya dengan istrinya yang sedang umoapi atau sara niwindahako maka denda korban yang pertama ditiadakan. Penyelesaian ini hanya bisa dilakukan jika korban atau suami yang dirampas istrinya menerima penyelesaian cara itu.

Kedua, Umoapi wali ndaa nidambangi atau perzinahan istri yang ditelantarkan. Penyebabnya adalah laki-laki yang menelantarkan istrinya karena dia memiliki istri lebih dari 1 orang, baik terhadap pemenuhan kebutuhan biologis, ekonomi maupun sebagai pelindung. Penyelesaian dari jenis umoapi ini adalah sama seperti umoapi wali ngginopukopu. Hanya untuk harta balireso atau harta gono gini, mereka semuanya jatuh ke tangan istri.

Umoapi seperti di atas, bila penanganannya melalui hukum adat tidak secepatnya, maka akan berakhir pada pembunuhan baik terhadap laki-laki yang merampas istri laki-laki (korban) atau dengan istrinya yang dirampas.

Perzinahan terhadap Tunangan Orang atau Umoapi Sarapu, apabila seorang perempuan yang sedang bertunangan dengan lelaki lain kemudian diambil tanpa sepengetahuan sang tunangan. Penyebab dari umoapi sarapu adalah karena sang perempuan tidak mencintai sepenuh hati tunangannya. Akibat adanya unsur perjodohan bisa juga karena faktor lingkungan.

Maka cara penyelesaiannya: pertama, Semua kerugian laki-laki tunangannya, dikembalikan oleh pihak laki-laki yang melakukan persetubuhan; kedua, Laki-laki yang melakukan persetubuhan diwajibkan membayar denda adat namanya Powea Sarapu atau pelepas tunangan. Atau dengan kata lain, lelaki yang merampas tunangan orang lain disebut mowea mohewu atau pelepas ringan, yang isinya adalah: 1 (satu) ekor kerbau hidup sebagai pondondono atau penyelamat batang leher, karena laki-laki tersebut sudah dianggap pernah mati lalu dihidupkan kembali oleh adat; 1 (satu) pies kain kaci sebagai petongano atau pengganti kain kafan alasannya karena orang mati harus dikafani; 1 (satu) cerek air sebagai wadah untuk menyiram batu nisannya atau pobubusino; 1 buah sawu pekopu atau sarung permintaan maaf.

Sesudah itu, barulah laki-laki yang merampas mengurus adat kepada orangtua perempuan yang dirampasnya. Adapun yang harus dilaksanakan adalah melanggahako/mekaleako atau berterus terang susunan acara adatnya adalah: Powoka biri atau pemberitahuan awal kepada keluarga pihak perempuan; Pelanggahako atau pernyataan sikap terbuka dari pihak laki-laki yang merampas; Taa pombona'akoa atau tindak pidana/penghukuman terhadap keluarga perempuan; Mekopu atau kembali baik kepada orangtua perempuan; Mesambepe atau bermusyawarah tentang niwindahako atau adat perkawinan dan onggoso ndekonggoa atau biaya pesta; Modandi atau penetapan hari $\mathrm{H}$ pelaksanaannya; Pernikahah boleh dilaksanakan saat itu juga mendahului pesta, juga boleh nanti bersamaan pestanya sesuai kesepakatan.

Umoapi Owese ini merupakan suatu perbuatan persetubuhan atau persetubuhan yang dilakukan oleh seorang laki-laki atau perempuan yang salah satu atau keduanya telah terikat dengan perkawinan yang sah baik menurut hukum tertulis maupun hukum adat Tolaki dan sedang terikat dengan hubungan pertunagan yang telah dilakukan secara adat.

Umoapi Owese ini jika dilihat dari aspek hukum positif Indonesia maka hukum adat Tolaki terkait dengan umoapi owose ini memiliki relevansi dengan Pasal 284 KUHP yang isinya menyatakan bahwa:

Pertama, Dihukum dengan hukuman penjara selama-lamanya sembilan bulan: Ke-1: a. Orang lakilaki yang sudah kawin, yang melakukan persetubuhan sedang diketahui, bahwa pasal KUHPerdata berlaku baginya; b. Orang perempuan yang sudah kawin, yang melakukan persetubuhan; Ke-2: a. Orang lakilaki yang turut melakukan persetubuhan itu, sedang diketahui, bahwa yang turut bersalah, sudah bersuami;

Kedua, Orang perempuan yang tidak bersuami, yang turut melakukan persetubuhan itu, sedang diketahui bahwa yang turut bersalah sudah beristri dan Pasal 27 KUHPerdata berlaku baginya.

Uraian tersebut di atas meskipun memiliki persamaan dalam pengertian persetubuhan di mana pihak yang melakukan tindak pidana persetubuhan telah terikat dengan perkawinan yang sah, namun dalam hal pengertian persetubuhan hukum adat Tolaki lebih mengatur secara komprehensip mengenai perbuatan persetubuhan yang dilihat dari aspek status pembuat persetubuhan dalam kaitannya dengan perkawinan pelaku dengan klasifikasi persetubuhan karena Umoapi Wali atau Persetubuhan Istri Orang, Umoapi wali ndaa nidambangi atau Persetubuhan Istri yang Ditelantarkan dan Umoapi Sarapu atau Persetubuhan Tunangan Orang. 
Perzinahan Biasa atau Umoapi Mohewu merupakan perbuatan persetubuhan atau persetubuhan atas dasar suka sama suka yang jika dilihat dari aspek hukum positif Indonesia perbuatan tersebut tidak dapat di pidana. Namun lain halnya dalam hukum adat Tolaki perbuatan yang didasarkan atas dasar suka sama suka dan keduanya belum terikat dalam perkawinan yang sah tetap dapat dinyatakan sebagai suatu perbuatan pelanggaran terhadap hukum adat Tolaki.

Persetubuhan biasa dalam hukum pidana adat Tolaki merupakan tindak pidana biasa di mana pelaku persetubuhan tersebut tidak terikat oleh perkawinan baik salah satunya maupun keduannya. klasifikasi perbuatan persetubuhan tersebut di bagi atas 2 jenis yaitu melakukan hubungan badan atau Moleloi dan menghamili perempuan atau Memboko Mendia yang akan diuraikan penulis sebagai berikut:

Pertama, Melakukan Hubungan Badan atau Moleloi. Prinsip melakukan hubungan badan disini adalah harus tanpa akibat dalam hal ini pelaku persetubuhan perempuan tidak hamil akibat persetubuhan yang dilakukan dengan seorang lakilaki yang bukan suaminya. Adapun sanksi adat yang dapat dijatuhkan oleh lembaga adat Kalo Sara adalah: Dikawinkan, tetapi; Kalau salah satu pihak menolak maka diharuskan membayar denda adat berupa: 1 pies kain kaci (tidak boleh diuangkan); 1 ekor kerbau (boleh diuangkan); 1 buah cerek air dari tembaga (tidak boleh diuangkan).

Kedua, Menghamili Perempuan atau Momboko Mendia. Seorang perempuan yang ketahuan hamil di luar nikah menurut pandangan orang Tolaki adalah sangat memalukan bagi keluarga perempuan. Apabila hal ini tidak secepatnya diselesaikan melalui lembaga adat Kalo Sara, tidak menutup kemungkinan terjadinya pembunuhan terhadap kedua pasangan persetubuhan dan jika pembunuhan tersebut dilakukan maka perbuatan tersebut dianggap oleh masyarakat adat Tolaki dibolehkan apabila pihak tersebut tidak mau menyelesaikan melalui hukum adat.

Adapun sanksi yang dapat dijatuhkan kepada pelaku persetubuhan yang berakibat pada kehamilan adalah: 1) Dikawinkan; 2) Kalau salah satu pihak menolak maka diharuskan membayar denda adat berupa: a) 1 pies kain kaci (tidak dapat diuangkan); b) 1 ekor kerbau (tidak boleh diuangkan)

Persetubuhan biasa atau Umoapi mohewu sebagai pelanggaran hukum adat dinyatakan sebagai suatu kesalahan yang masuk dalam klasifikasi tindak pidana biasa, jika mengacu pada uraian mengenai perbuatan persetubuhan biasa dalam hukum pidana adat Tolaki terlihat ada perbedaan konsep hukum pengertian dalam Pasal 284 KUHP yang hanya dapat mengikat pelaku persetubuhan jika keduanya atau salah satu dari pembuat delik terikat dengan perkawinan yang sah.

Pasal 284 KUHP tidak mampu mengakomodir atau menjangkau pembuat persetubuhan yang didasarkan atas suka sama suka yang belum terikat perkawinan oleh pembuatnya akibatnya tidak memberikan keadilan dan kemanfaatan hukum bagi perempuan yang melakukan perbuatan persetubuhan tersebut meskipun perbuatannya dilakukan bukan atas sebuah paksaan. Namun demikian akibat hukum dari perbuatan tersebut dapat merugikan perempuan.

\section{PENUTUP}

\section{Kesimpulan}

Berdasar uraian isu hukum dalam pembahasan di atas, maka kesimpulan yang dapat diperoleh penulis dari analisis tersebut adalah persetubuhan baik menurut hukum pidana dan hukum adat Tolaki memiliki pandangan yang sama di mana persetubuhan dianggap merupakan perbuatan melawan hukum dan patut untuk diberikan sanksi pidana atas pelanggaran tersebut. Namun demikian, hukum adat Tolaki dalam konsep klasifikasi persetubuhan lebih mengatur secara komprehensif tentang perzinahan, di mana perbuatan zina tidak hanya terbatas pada mereka yang telah terikat dengan perkawinan sebagaimana dimaksud dalam Pasal 27 BW tetapi mengikat pula bagi mereka yang belum terikat perkawinan dengan klasifikasi perzinahan dengan pemberatan atau umoapi owose dan perzinahan biasa atau umoapi mohewu dengan penerapan sanksi adat Tolaki yang berbeda-beda berdasarkan klasifikasi jenis perzinahannya atau umoapi yang telah dilakukan dalam hal ini makin berat kualifikasi delik yang dilakukan maka konsekuensi pemidanaannya semakin berat pula.

\section{Rekomendasi}

Untuk melengkapi analisis ini berikut akan di uraikan rekomendasi yang berisi tentang solusi dari isu hukum yang telah diteliti adalah sebagai berikut:

Pertama, Pengakuan terhadap hukum adat dapat meminimalisir terjadinya kekosongan hukum di dalam hukum positif Indonesia. 
Kedua, Adanya jaminan perlindungan hukum terhadap korban tindak pidana perzinahan dengan mengakui pemberlakuan hukum adat dalam hukum positif Indonesia.

\section{DAFTAR PUSTAKA}

\section{Peraturan Perundang-undangan:}

Kitab Undang-Undang Hukum Pidana.

Kitab Undang-Undang Hukum Perdata.

Undang-Undang Nomor 1 Tahun 1946 tentang Peraturan Hukum Pidana.

\section{Buku:}

Departemen Pendidikan dan Kebudayaan, 1989, Kamus Besar Bahasa Indonesia. Jakarta: Balai Pustaka.

Hatubi, Abd. Latif Parase, 2006, Buku Panduan Adat Tolaki Kabupaten Konawe, Isi Lokakarya Univikasi Hukum Adat Sarano Tolaki, Kendari.

Marpaung, Leden, 2004, Kejahatan terhadap Kesusilaan dan Masalah Prevensinya, Jakarta: Sinar Grafika.

Muhammad, Bushar, 2006, Asas-asas Hukum Adat Suatu Pengantar, Jakarta: Pradnya Paramita.

Moeljatno, 2008, Asas-Asas Hukum Pidana Edisi Revisi, Jakarta: Rineka Cipta.
Poeponoto, Soebekti, 1980, Bab-bab tentang Hukum Adat, Jakarta: Djambatan.

Poernomo, Bambang, 1994, Seri Hukum Pidana 1 Asas-asas Hukum Pidana, Jakarta: Ghalia Indonesia.

Prodjodikoro, Wirjono, 2003, Azas-Azas Hukum Pidana Indonesia, Bandung: Refika Aditama.

Pujosewojo, Kusumadi, 1971, Hukum Adat, Jakarta: Sinar Grafika.

Sa'abah, Marzuki Umar, 1997, Seks \& Kita, Jakarta: Gema Insani Press.

Sihombing, 2007, Pengantar Hukum Adat Indonesia, Jakarta: Toko Gunung Agung.

Soedjono, Dirdjosisworo, 1991, Hukum Pidana Indonesia dan Gelagat Kriminalitas Masyarakat Pasca Industri, Jakarta: Sinar Grafika.

Soegandhi, 2000, Kejahatan terhadap Kesusilaan, Jakarta: Bina Aksara.

Soekanto, Soerjono, 2005, Hukum Adat Indonesia, Jakarta: Raja Grafindo Persada.

Tarimana, Abdul Rauf, 1989, Kebudayaan Tolaki, Jakarta: Balai Pustaka.

Tongat, 2009, Asas-asas Hukum Adat, Jakarta: Pembangunan. 